\title{
Chinese Americans and Cityhood Movement in Hacienda Heights in 2003
}

\author{
Hung Yu-Ju \\ Chinese Culture University, Taiwan \\ Email: hyr11@ulive.pccu.edu.tw
}

Received 4 August 2015; accepted 27 September 2015; published 30 September 2015

Copyright @ 2015 by author and Scientific Research Publishing Inc.

This work is licensed under the Creative Commons Attribution International License (CC BY). http://creativecommons.org/licenses/by/4.0/

(c) (7) Open Access

\begin{abstract}
Cityhood incorporation is a common local issue in the American local history regarding different political, social, and economic factors. However, the creation of municipality becomes more controversial agenda in certain local regions when suburban ethnic communities are rapidly created by post-1965 immigration. It is reflected by the cityhood movement in Hacienda Heights in 2003, when Chinese/Taiwanese immigrants added ethnic elements in these public and civic activities. This study provides further observation and investigation to the impact that Chinese capitalize on their ethnic and non-ethnic social networks to increase their power in the community-based civic matters, while showing various dimensions on the responses from local multiethnic communities.
\end{abstract}

\section{Keywords}

Chinese American, Immigration, Ethnoburb, Eastward Migration, San Gabriel Valley, Hacienda Heights, Cityhood Movement, HHIA, HHCA

\section{Introduction}

Since the late nineteenth century, the cityhood movement is a common local phenomenon in the United States with regards to the sharing of local political power by diverse groups, multi-ethnic relationship, local economic growth, as well as the choice of different community-based lifestyles among local people. Nevertheless, the engagement of Chinese in this kind of issue only commenced in the latter half of the twentieth century when a flood of new Chinese immigrants, motivated by the American reform in 1965, created apparent suburban ethnic communities, what Geographer Wei Li termed as "ethnoburb" (Li Wei, 1998). ${ }^{1}$ These post-1965 Chinese American immigrants mostly distinguish themselves from traditional Cantonese Chinese who arrived in the ni-

\footnotetext{
${ }^{1}$ The notion of ethnoburb was created by Chinese ethnic scholar Wei Li to define the presence of modern ethnic community and its business
} activities in the United States, interlinking with global migration and economic growth, as well as American suburbanization. 
neteenth century, with their resourceful economic capital, professional background, and capability to conform to the mainstream labor market. On the one hand, these characteristics facilitate Chinese immigrants in the post1965 to bypass the inner-city Chinatowns, and directly settle in the suburbs. This is considered by most Americans as being at odds with the conventional concept that immigrants will experience intergenerational growth and advance the social ladder marked by residential transformation. On the other hand, the flow of transnational social capital, staunch pre-immigration socioeconomic status, and professional attainment empower Chinese new immigrants with selective assimilation patterns: possessing the ability to retain original cultural endowment and engagement in transnational and local activities as an alternative path to social and economic achievement in the United States (Portes, 1999; Levitt, DeWind, \& Vertovec, 2003). This selective assimilation is proved to be efficient in many aspects of immigration community, particularly their participation in the local politics (Wen, Lauderdale, \& Kandula, 2009, and etc.). ${ }^{2}$ In this study, a careful examination of Chinese local political and civic participation in controversial cityhood movement in Hacienda Heights, an unincorporated area in a Los Angeles suburb, is examined. The study focuses on how Chinese capitalize on their ethnic and non-ethnic social networks to increase their power in community-based civic matters, and show the response from local multiethnic communities.

\section{The Development of the Chinese Community in Hacienda Heights}

The emergence of Chinese community in Hacienda Heights, an unincorporated area in the inland suburbia of Los Angeles County, is the epitome of post-1960s Chinese American immigration to southern California. This influx of Chinese immigrants and investors, mostly from the Pacific Rim, began to settle in the San Gabriel Valley $^{3}$ by selecting Monterey Park, locating in the west edge adjacent to Los Angeles, as their first area of settlement in 1970s. Fueled by Taiwanese and Chinese realtors, developers, and businessmen, Monterey Park was well advertised in Asia as the Chinese Beverly Hills, attracting incessant immigrants from Taiwan and Hong Kong. By the mid-1980s, Taiwanese nearly made up half of the city population, completely remodeled the city as a Taiwanese-style one with nickname of "Little Taipei", or historian Timothy Fong defined as the "first suburban Chinatown". The arrival of Taiwanese, following the Chinese immigrants, not only transformed the local demography, but also brought tremendous change in the local economy and landscape. Taiwanese-owned office buildings, supermarkets, mini-malls, and restaurants had replaced the original community's commercial center, the Garvey Boulevard and Atlantic Boulevard, with a cosmopolitan Asian Pacific hub, and prominent Chinese language signs lined the main streets, leading to phenomenon of white flight (Dyer, 1961; Fong, 1994; Arax. 1987). This Taiwanese and Chinese “intrusion” caused serious backlash that made Monterey Park being plagued by racial conflict in local politics and elections (Fong, 1995; Horton, 1994; Saito, 1998).

In the years since 1980s, additional stages of Chinese migration related to the eastward movement was conducted by Taiwanese, following Mainland Chinese immigrants who flooded the area after 1990. Insufficient space and skyrocketing land prices in Monterey Park and nearby cities in the western San Gabriel Valley, along with the disincentive factor of subsequent new Mainland Chinese immigrants, forced settled Taiwanese to migrate eastward to the interior suburbia. As a result, a locally labeled "Chinese Golden Triangle Area”, had been staunchly formed in the aftermath of mid-1990s (Schoner, 2006). ${ }^{4}$ Hacienda Heights was the first settled Chinese (Taiwanese) community in this eastward migration in the San Gabriel Valley.

In nineteenth century, Hacienda Heights was part of the Rancho La Puente owned by John A. Rowland and William Workman (Diaz, 2005). As a traditionally agricultural town, Hacienda Heights, renamed from North

\footnotetext{
${ }^{2}$ Many researchers of transnational minority suburban communities indicated that there were "resurgent ethnicity" in suburban neighborhoods, particularly the promotion of their political and civic participation. For instance, Francisco Jimenez, Alma M. Garcia and Richard A. Garcia had observed that post-1960s Mexican suburbanites in San Jose, California, had utilized Latino cultural and religious institutions to channel their ethnic power in pursuit of their political and civil rights; Linda Trinh Vo's investigation of the Vietnamese community in Orange County, California also reflected how the Vietnamese depended upon their ethnic economic networks to create a self-choosing incorporation; Similarly, the examinations of Asian and Latino political activities in Los Angeles from John Horton and Leland T. Saito also reflected the ethnic selective assimilation pattern in political arena. These two authors observed that Asians and Latinos both achieved political successes by their demographic advantage and ethnic mobilization in Los Angeles suburbs.

${ }^{3}$ The San Gabriel Valley is a vast suburban area of Los Angeles County, one of the most significant ports of Chinese immigration to the United States since the early twentieth century. The region extends to a large area geographically: West to the Los Angeles City, East to San Bernardino County, North to the San Gabriel Mountains, and South to Puente Hills. In 2012, the San Gabriel Valley encompassed 31 small-to-medium cities and 14 unincorporated towns, each with populations ranging from thirty thousand to hundreds thousands. Hacienda Heights is one of the unincorporated area locating in the southeastern San Gabriel Valley.

${ }^{4}$ It encompassed two unincorporated areas, Hacienda Heights and Rowland Heights; two incorporated cities: Walnut and Diamond Bar.
} 
Whittier Heights in 1961 after a community petition, gradually transformed itself into a suburban sleepy community in the 1950s and 1960s when European Americans started to develop their residences in subdivision of Kiwis Avenue and nearby blocks. In the 1970s, large scale of single-family housings were developed in Hacienda Heights, particularly along the northern slopes of Puente Hills, and attracted many younger, affluent and educated families. The construction of Pomona Freeway in 1970s further incorporated Hacienda Heights into a new option for Los Angeles suburbanites. Following this trend, a small group of Chinese homebuyers began to move into this area in mid-1970s (Bond, 1990).

Cultural and religious reasons were responsible for Chinese preference to this area as well. The establishment of Hsi Lai Temple was a driving force to move to this area. Founded by the monk Master Hsing Yuan, who formed the Fo Guang Shan Buddhist Temple in Kaoshung city, Taiwan, Hsi Lai Temple was an overseas branch of Fo Guang Shan and the largest Buddhist temple complex in the Western Hemisphere. After its completion in 1988, Hsi Lai Temple soon became the prominent Buddhist center in the United States and hosted a large number of Chinese and non-Chinese pilgrims and tourists in the succeeding decades (Torres, 1988; Newton, 1988; Chang, 1990). Several local Chinese immigrants I interviewed, especially those moved to this town before 1990, indicated that religious and cultural attract ability was the magnet that drew people to Hacienda Heights.

From 1980s to 2000, Chinese/Taiwanese population in Hacienda Heights rose from 1483 in 1980, 7853 in 1990 to 12,553 in 2000. In 2000, Chinese/Taiwanese constituted 24.3\% of total population in Hacienda Heights, slightly exceeded white residents (22.5\%), but second to largest ethnic Latino residents (38.1\%). In 2010, Comparing to Latino (45.5\%) and white $(14.9 \%)$ residents, Chinese/Taiwanese sustained their ethnic ratio in Hacienda Heights $(24.1 \%)$ as the second largest ethnic group (U.S. Census, 2000; 2010). Presently, Hacienda Heights, along with its nearby Rowland Heights, are notable as "Little Taipei", with intense concentration of ethnic populations who have their own businesses, restaurants and stores (Chee, 2005; Bond, 1996, Klein, 1997; Hamilton, 1995; Wysocki Jr., 1996, and etc.).

With more Chinese (Taiwanese) Americans settled in the Hacienda Heights in the aftermath of 1990s, Chinese created local ethnic clubs, while also engaging aggressively in existing community organizations. Chinese Associations or hua shai is most common for local Chinese in Hacienda Heights. Established in 1983, Hacienda Height Chinese Association (HHCA) not only assisted newly-settled co-ethnic migrants to settle down, but also linked these migrants with Chinese schools. According to Philip Mo, HHCA was formed by people of Hacienda Heights Area Chinese School (founded in 1982). ${ }^{5}$ They aimed to utilize the non-profit status of hua shai as a fundraising organization, keeping the language school in long-term operation. Another vital function of HHCA was, on behalf of local Chinese parents, to deal with local public schools, and help young Chinese students' to adapt with problems on the campus. Considering that no Chinese person was elected to sit on the board of directors of Hacienda La Puente Unified School District (HLPUSD) until the early 1990s, hua shai became a significant vehicle for local Chinese parents to depend upon. The early leaders in HHCA, such as Norman Hsu, tried soundly to link its operation to local American organizations, such as Rotary Club and Lions Club, to gain credibility for negotiation. These efforts not only benefited mutual communication with local schools but also promoted HHCA as an ethnic representative platform forpublic offices in the following years. ${ }^{6}$

Aside from the creation of ethnic network of HHCA, Chinese also actively participated in existing community organizations. HHIA is the representative club that local Chinese most engages. In essence, the HHIA is a private homeowners association that unofficially supervised the area and acted as a quasi-city-council to the Board of Supervisors of Los Angeles County, which controlled all the funds for unincorporated areas across Los An-

\footnotetext{
${ }^{5}$ This school was created by Lin-yuan Sun and his Taiwanese fellows. Starting by a "garage pattern", this school was fully operated and funded by voluntary Chinese parents. During its early days, this school frequently relocated itself due to insufficient budget to rent a permanent spot. However, as the first Chinese weekend-school formed by post-1960s Chinese immigrants surrounding Hacienda Heights, it gained sound support from local Chinese/Taiwanese, giving rise to the expansion of its student body and the number of classes in this period, from only 40 students (one class) in 1982 to over 600 in 1990, with 20 different classes, including several after-school classes. Since that the school was mainly owned by eastward Taiwanese migrants, it was well cooperated and sponsored by Taiwan's Overseas Chinese Commission, which provided textbooks and instructors from National Taiwan Normal University. Hence, standard Mandarin character and phonetic system, the way Taiwan used in its public education system, was also applied in this school in early times. Nevertheless, the changing demography in the east San Gabriel Valley gradually transformed school's component, adding by overwhelming students from Mainland China. It altered school's board of trustees, and brought a different instruction way, with the introduction of simplified Chinese character and pin-yi system, the way prevailing in Mainland China. Nowadays, the Hacienda Heights Area School utilized a dual policy to serve the demand of its students from different origins of countries. Interview with Jeffery Tsang, Date: August 22, 2011; Interview with Philip Mo, Date: August 23, 2011.

${ }^{6}$ Interview with Anyoke Lee, Date: March 10, 2012; Interview with Judy Chen Haggerty, Date: May 3, 2012.
} 
geles County. ${ }^{7}$ Established in 1955, HHIA advocated for local needs, such as road maintenance, public safety and recreation opportunities. The HHIA also led and participated in nearly every significant local activity in Hacienda Heights in the second half of the twentieth century: negotiating with Regional Planning Commission of Los Angeles to give birth to a Community General Plan in 1974, which presided over the area' subsequent growth and land use; organizing two unsuccessful fights to block the nation's largest landfill and its expansion in the local hillside bordering Whittier in 1983 and 1993; involving three attempts of Hacienda Heights cityhood movements in 1982, 1992 and 2003 (Hsu, 2005; Dai, 2005; Winton, 1993; 1994, etc.).

The composition of the HHIA gradually evolved in its half-century history, keeping pace with local demographic change: from mainly-Europeans in prior to the 1980s, to a diverse mix of whites, Latinos and Asians members in the aftermath of 1990s. Among the non-European members, the Chinese were one of the earliest ethnic groups involved in HHIA. These Chinese forerunners mostly were representatives from HHCA and the Hsi Lai Temple, whose participation was mission-oriented: trying to reduce the local hostility against Chinese/ Asian newcomers and served as communication conduits. In the 1990s, more local Chinese political activists, such as Norman Hsu, Cecilia L. Yu, Eugene Chang, David Fang, Joseph Chang, along with some Chinese residents, more fully engaged the organization. As Norman Hsu noted:

The early Hacienda Heights Chinese usually remained within ethnic-based organizations such as Chinese Association and Chinese PTA, and focused exclusively on the arena of schools. They seldom contacted local American organizations, such as HHIA, Rotary Club and Kiwi Club. However, in 1990s, many local Chinese felt the necessity to express their opinions beyond the school issue, and some Chinese pioneers started to build friendship with senior members of HHIA, such as Barbara Fish, for critical local issue such as the landfill expansion. This Chinese small group began to attend the monthly meetings of HHIA although Chinese were still a minority group in HHIA, and seldom Chinese were in the European American-dominated board of directors. ${ }^{8}$

This remark by Norman Hsu both expressed the intention and constraints of Chinese participation in local American organization in 1990s. Although Hacienda Heights had transformed into a multi-ethnic community after the 1980s, the local HHIA still was controlled by European locals, which constituted over 70 percent of its 500 registered members, and took up most seats of its board directors. For instance, Barbara Lee Fish, a longtime community leader, who served as the president of HHIA for five terms (ten years); Mike Hughes, another long-term resident, filled 8-year long terms as president in the period of 1996 to 2000s (Wagner, 2010). Another local community activist, Mike Williams, was the president of the HHIA for two times in 1990s and mid-2000s. As a result, the Chinese usually participated as observers, rather than become part of decision-making in this comparatively conservative and European-dominated organization in 1990s. Nevertheless, contact and participation with this organization had laid the foundation for Chinese voices on local matters in the future.

The Chinese had increasingly become a significant group in the HHIA during the 2000s, reflected by rising membership enrollment, which increased from 30 in 1990s to nearly 100, nearly one-fifth of the membership in HHIA in 2012. The Chinese also became active on the board of the HHIA. In 2005, the local president of Chinese PTA, Tom Chang, was elected to the board of directors for the HHIA, while in 2010 three seats were filled by local Chinese/Asians: Shan Lee (chairman of zoning commission), Mae Chu (chairwoman of public relations commission) and Chris Kakimi (treasurer). As of 2012, Chinese/Asians still occupied three of the twelve seats of the board: Shan Lee (zoning commission chairman), Jeffrey Lin (Street \& Highways commission chairman) and Chris Kakimi (treasurer). This growing ethnic influence in HHIA was not only shored up by increasing Chinese enrollment, but also the product of active Chinese community service. For instance Mae Chu in HHIA's public relations commission was highly connected with her work as the speaker at the Hsi Lai Temple. It symbolized an appreciation of HHIA for contribution of the Hsi Lai Temple and the expectation for practical improvement for the relationship between the Chinese and the local community. Shan Lee's service in the board of HHIA was tied to his working experience on the Los Angeles County Business License Board. This let the HHIA use his professional and guan xi network at the county level. ${ }^{9}$

\footnotetext{
${ }^{7}$ According to its bylaws, HHIA regularly holds meeting on the third Monday monthly at office the Hacienda La Puente School District. HHIA is governed by 12-person board of directors elected by the members. In its monthly meeting, local elected officials such as the board directors of Hacienda La Puente School District and Water District, as well as the Los Angeles County's Fourth District's Supervisor or his/her field deputy are necessary attendants to discuss about the local affairs and issues.

${ }^{8}$ Interview with Norman Hsu, Date: June 21, 2012.

${ }^{9}$ HHIA, Newsletter, January, 2010; HHIA, Newsletter, April, 2010; HHIA, Newsletter, February, 2011; HHIA, Newsletter, January, 2012.
} 
The growth of Chinese influence not only was manifested by increases in membership for the HHIA, but also marked by their growing power over policy-decision concerning local matters. For example, the Chinese heavily championed the Hacienda Heights Fourth of July Parade, the most significant annual celebration run by the HHIA. This parade was started by local activist Barbara Lee Fish in 1988. Most local Chinese organizations, including the Hsi Lai Temple, Hacienda Heights Chinese Association Hacienda Heights Area Chinese School and Taiwan American Association of East San Gabriel Valley, were the prime financial source for this parade in the 2000s. Nearly half of volunteer teams were Chinese-organized in the last decade. As Denny Wood, board director of HHIA, remarked: "Chinese support and participation for this Parade proved that they were part of this community. They were no longer a foreign group to me."10

Hacienda Heights Beautification Day was another local activity that various Chinese local organizations fully supported in the HHIA. In 2011, over 100 people from Hsi Lai Temple and Hacienda Heights Chinese Association participated in this event. In 2010, many Chinese volunteers joined the "volunteer on patrol" program; a program coordinated with the local sheriff station to aid the security of neighborhoods. The Chinese also actively responded to the Census Community Walk that HHIA launched on March 27, 2010. The Hsi Lai Temple and the Chinese members of the School District Board of directors, such as Jay Chen, with about 40 Chinese volunteers sponsored this program. This intense participation and funding for local activities enlarged Chinese voice and weight within the HHIA. ${ }^{11}$

Since the mid-1980s, Chinese/Taiwanese immigrants demonstrate growing influence in Hacienda Heights, reflected by growth of their ethnic population, concentration of ethnic economy, and most significantly, their involvement in diverse social organizations in their neighborhoods. Instead of being conventional passive ethnic minorities, this selective assimilation pattern empowers Chinese suburbanites with momentum to create ethnic voices in local issues, evoking different responses in their community. The cityhood movement in 1990s to early 2000s serves as a good example to measure how public agenda is mutually reciprocated by ethnicity.

\section{The Incorporation Issue and Local Politics}

Generally speaking, municipality pursuing activities were not rare in the American local history, particularly in California. The ratified Californian constitution in 1879 and the passage of Municipal Corporations Act of 1883 first enabled local residents to vote in a general election for incorporation, leading to a total of 88 unincorporated regions in Los Angeles County turning into cities through ballot initiatives in the following century. Among them, 11 cities were formed in the nineteenth century, while 36 and 38 unincorporated areas had incorporated in the first and second half of the twentieth century, respectively. Historically, two major growth periods for cityhood in Los Angeles County occurred, the first one in the early twentieth century through 1930, and the other one beginning in the 1950s and extended to the late 1980s. The first period coincided with a great influx of migrants to the county when it began to take shape as a modern metropolitan area. The second period was paced with postwar suburbanization and accelerated by the "service-contract plan", suggested by new city of Lakewood in 1954. This plan allowed newly-founded cities with limited public employment to negotiate with their county governments and other private units for purchasing public services. The Lakewood case proved an attractive pattern for suburbanites to gain local-control without incurring the expenses of creating a full-service municipality. Besides, the passage of California's bill of one-percent local sales tax in 1956 also created an important new source of revenue for local governments, making cityhood more viable in many communities with extensive retailing businesses (Lewis, 2000; Schiesl, 1982; Bollans \& Scoot, 1951).

Moreover, the passage of Proposition 13 of 1978, a property tax limitation initiative, further produced a niche for cityhood proponents. In the past, fears that taxes would increase had allegedly been a major disincentive to incorporation. But the property tax rate freeze made by Proposition 13, to a certain extent, counteracted this disincentive. Incorporation would not add any net property tax burdens to property owners in that area, unless their rate had been below the low maximum rate of one percent established by Proposition 13. In addition to the contextual regulations, other parameters such as inter-governmental competition, annexation, water resource sharing, or fiscal limitations were also motives to drive people to take actions for cityhood in order to protect their rights from the threats of neighboring cities. Therefore, all these factors led to a flurry of incorporation happening in

\footnotetext{
${ }^{10}$ Chinese Daily News, July 5, 2008; Chinese Daily News, July 5, 2009; Chinese Daily News, July 5, 2010; Chinese Daily News, July 5, 2011 Chinese Daily News, July 5, 2012.

${ }^{11}$ HHIA, Newsletter, April 10, 2010; HHIA Newsletter, February, 2011; Bethania Palma Markus, "Beautification Project in Hacienda Heights Reaches its Final Stages,” Whittier Daily News, December 5, 2008.
} 
Los Angeles County particularly in 1960s to 1980s. This made the number of residents living in unincorporated areas had declined since 1960s, from 7.1 million, nearly 15\% of the Los Angeles County's population, in 1974 to approximately one million in 2012. Following this trend, Hacienda Heights also launched several incorporation attempts in the aftermath of 1980 (Lewis, 2000; Krikorian, 1994). ${ }^{12}$

In order to deal with growing requests for incorporation and complex local governmental issues, the Californian State Legislature in 1963 created a new monitoring agency for urban growth, the Local Agency Formation Commission (LAFCO) in each county. Acting as a government entity, LAFCO was empowered to decide boundary, annexation, special districts, and incorporation issues. LAFCO was essentially comprised of representatives from local cities and representatives of the County board of supervisors. As a result, a town's incorporation attempt usually involved regional, even to the county-wide, political competition (Goldbach, 1965).

In prior to 1985, LAFCO had mandated a series of complicated statutory laws and three enabling acts, the Knox-Nisbet Act of 1963, the District Reorganization Act of 1965 and the Municipal Organization Act of 1977. However, longstanding confusion in implementing and reconciling these distinct, and at times incompatible, laws led the Legislature to draft the Cortese-Knox Local Government Reorganization Act in 1985, a combination and revision of the three acts. The Cortese-Knox Local Government Reorganization Act of 1985 provided the framework within which proposed city annexations, incorporations, consolidations, and special district formations are considered. Afterwards, in 1997, a new call for reform in local government resulted in the formation of the fifteen-member "Commission on Local Governance for the 21st Century" (CLG21). CLG21 finalized the updated version of Cortes-Knox-Hertzberg Local Government Reorganization Act of 2000, an act that mandated greater independence for LAFCO in 58 California Counties, and further clarified their mission on local government arrangement. ${ }^{13}$

According to Cortese-Knox Local Government Reorganization Act and Cortes-Knox-Hertzberg Local Government Reorganization Act, the application for a cityhood essentially required several step-by-step stages: (a) to consult with LAFOC and propose an initial feasibility review; (b) to submit an incorporation petition with signatures of at least 25\% local registered voters; (c) if the petition is approved by LAFCO, then a comprehensive fiscal analysis (CFA), testifies the fiscal self-support once the municipality attained, is required to submit. LAFCO will then review all the application materials, perform environmental review, determine revenue neutrality payments, and produce a final report. If the incorporation proposal is approved and there is no opposition for 30 days, then the incorporation will be placed on the ballot of the next general election or a special election. The incorporation will be completed when a simple majority of the voters votes for it. If the election result discouraged the incorporation, a ten-year suspension will be exercised before another cityhood proposal (Smith, 2011). ${ }^{14}$

\section{Chinese Involvement in Hacienda Heights Cityhood Activities}

Hacienda Heights incorporation efforts dated back to the early 1970s. In 1971, when the HHIA had sponsored a three-year study regarding Hacienda Heights cityhood, and asked the LA County’s Chief Administrative Office to appoint an "Incorporation Feasibility Committee” to pursue the issue (Frank, 1971). Afterwards, a fifty person organization, "Hacienda Heights City Incorporation through You”, was formed in 1974 and examined the possibility to launch a cityhood ballot in the 1976 general election (Barker, 1974). These early incorporation efforts were highly concerned with "growing pains" in the wake of a skyrocketing suburban population. These community members sought more input on local zoning, which they thought was compromised by Los Angeles County without consideration of local interests.

Hacienda Heights incorporation happened in 1982, initiated by the HHIA in reaction to two local events. First, in January 1980, LAFCO set aside spheres of influence 1200 acres from Hacienda Heights to nearby Whittier and about 1000 acres on the southern border to the City of Industry. Spheres of influence are used as planning guides for cities or unincorporated areas as the County plans their ultimate physical boundaries. Therefore, LAFCO's decision for the annexation of the undeveloped land of Hacienda Heights disappointed some residents who thought that the creation of a municipal government might work against the possible territorial annexation and control their own community. Secondly, in 1982, a trash incinerator and a large landfill were proposed to be

\footnotetext{
${ }^{12}$ Paul G. Lewis, “The Durability of Local Government Structure: Evidence from California”: 42-43; Los Angeles County Government website: http://www.lacounty.gov/wps/portal/lac/residents/unincorporated.

${ }^{13}$ LAFCO website: http://www.lafco.org/opencms/index.html.

${ }^{14}$ Governor's Office of Planning and Research, A Guide to the LAFCO Process for Incorporations: October 2003: 1-26.
} 
located in Hacienda Heights's west hill section bordering Whittier. This landfill project, which later known as Puente Hills Landfill, was supposed to bring environmental impacts and pollution upon the neighboring community, particularly Hacienda Heights and La Habra Heights. It forced many Hacienda Heights locals to consider incorporation as a solution to stop the establishment of this gigantic project (Trounson, 1980; Barker, 1981).

As a result, in early 1982, led by HHIA, the cityhood activities soon drew dozens of volunteers (Birkinshaw, 1982). In hoping to place the incorporation issue in the general election on November 2, the cityhood proponents mobilized the petition and collected 5612 signatures, a slightly more than the required 5579 (25\%) registered voters in early August. However, this incorporation attempt was invalidated by LAFCO, which, after examination of the application materials, noting that 36 signatures might be forged. This forgery-signature affair soon discouraged the incorporation drive.

There were a multitude of reasons to explain the failure of Hacienda Heights' first incorporation action, but main evidence pointed out that as a town with majority of conservative residents, most locals intended to keep their community as the same without another costly layer of bureaucracy. Many of them were afraid of expected tax increases once cityhood was attained. Besides, local people also worried that incorporation was a conspiracy on the mask of developers, such as A. E. Watwood, which they thought would alter their rural community. This camp against cityhood was represented by "United Against Cityhood", which was formed in July 1982. They organized to dismiss the incorporation application by several steps. First, they united members of HHIA to vote the board supporting incorporation out of office and transformed HHIA to neutral on the incorporation agenda. Secondly, they launched investigations regarding the application process, and impeached fraud signatures to LAFCO that eventually failed the incorporation application (Avery, 1981; Birkinshaw, 1982, and etc.). Afterwards, the first attempt of incorporation in 1982 was followed by a second fledgling incorporation drive, which fell apart, with only about 700 signatures collected in 1985.

\subsection{The Cityhood Movement in 1992}

With the extensive discussion and debate in 1970s and 1980s, Hacienda Heights was more optimistic for its cityhood prospects in the early 1990s. First of all, the incorporation issue was supported by many local organizations, like HLPUSD and HHIA, which was headed by longtime cityhood proponents such as Barbara Fish and Michael William. Secondly, the planned expansion of the Puente Hills Landfill in 1992 enraged more locals, many of them, represented by the "Angeles Chapter of Sierra Club", which had already fought the landfill for years. This growing group of "Hacienda Heights homeowners" against landfill developers became a solid base to persuade locals for cityhood (Hudson, 1990; Lepage, 1994). Thirdly, cityhood proponents gained stronger support from Los Angeles County District 4 Supervisor, Deane Dana. The support of Deane Dana showed a clear shift from former Supervisor Pete Schabarum, who stayed neutral toward Hacienda Heights cityhood activities. Last but not least, the power of anti-incorporation camp was gradually weakened, making no organized effort to oppose this incorporation bid. Besides, the saturation of local economy in 1980s and early 1990s, to a certain extent, also calmed locals that further commercial growth would be limited once incorporation was achieved. The County's report that an incorporated Hacienda Heights would have a \$2.2 million budget surplus also reduced doubt from locals. All these effectively contributed to dismantle anxieties of cityhood opponents. For example, David T. Romero, an anti-cityhood activist in 1982, changed his mind to support incorporation in 1992 because he thought the finance would be self-sustaining (Chang, 1991; 1992). Hence, unlike the former attempts ended up in the petition stage, this incorporation activity successfully collected 6,707 signatures, representing $28 \%$ of 22,764 voters in the area, in April, 1992. After submitting all petition materials to LAFCO, Hacienda Heights's incorporation, the Measure C, was scheduled in general election on June 2, 1992 (Chang, 1991, and etc.).

Accompanying with the vote for the municipality, Hacienda Heights residents also would choose a fivemember city council—should incorporation pass—and decide whether future councils should be elected at large or by district. This first-time city council election galvanized enthusiasm of local political activists: sixteen candidates were registered in this election. Among them, seven persons were involved in the HHIA or HLPUSD: Lillian M. Avery, Wil Baca, Jackie Graham, Gloria Nunes, David T. Romero, Bill Torres and C. A. Welch. Both Wilfred Baca and Lillian M. Avery claimed themselves as the representatives who opposed the dump expansion. There were also four candidates with backgrounds as developers or commercial businessmen: George R. Hensel, president of five corporations, including the California Driving School and a real estate property management 
company; David T. Romero, a self-employed management consultant; Ellis Swing, a businessman involved in international trade; Diana E. Wood, 59, a local realtor. Other candidates mostly were professionals, including two attorneys, two medical doctors, and two former police officers (Chang, 1992).

The sixteen candidates vying for the five city council seats came from different ethnic groups, including four Hispanic candidates: Wil Baca, David T. Romero, Rudy Almeida, and Gloria Nunes; two Chinese candidates: Eugene Y. Chang, an engineer in the Los Angeles County Department of Public Works; Cecilia L. Yu, a local attorney. The rest of ten candidates were with European descents. Two Chinese and four Latino candidates into the municipality-pursuing election reflected the demographic reality that Hacienda Heights was in the process of formation of a heterogeneous community: with 31\% Latino residents, 27\% Asian population, and about $40 \%$ European inhabitants in 1992. The presence of six non-white candidates in 1992 signified for the first time an involvement of minority groups, including Chinese who transformed the political processes in Hacienda Heights (Chang, 1992; U.S. Census, 1990).

Although a combination of factors made local community activists feel hopeful for municipal involvement, the turnout of Measure $\mathrm{C}$, however, demonstrated a disappointing result: the proposal for cityhood was rejected by a slim margin: with 5245 "Yes" ballots (47\%), and 5929 votes No (53\%). The failure to vote for the incorporation in Hacienda Heights might be attributed to a sustaining force of established European residents who voted against this incorporation, while attitudes of minority groups toward this agenda was another determinant. Despite these results, no concrete statistics indicated that ethnic groups influenced this agenda; however, it was certain that discussions about cityhood and exchange of information were limited among European residents. Under these circumstances, non-white community leaders showed less concerns for the impact of incorporation itself; instead, they focused on the pseudo-city elements of electing a council. Chinese voters, in particular, voiced their support for selecting council members and not realizing that the outcome of incorporation was a meaningful and significant venture.

Despite the fact that Chinese and other minority groups demonstrated a weak inclination to vote for the incorporation agenda, their enthusiasm to select members for the pseudo-city council was never ending. Under the voting regulations, each local electorate was able to cast five votes and three minority candidates were among top five ballot-earners: Wilfred Baca, 4658 (11\%), Eugene Y. Chang, 3537 (9\%); and Cecilia L. Yu, 3348 (8\%), with two white candidates, Charles M. House, 4411 (11\%); George R. Hensel, 3713 (9\%). It showed that minority representatives would be the majority if the Measure C was passed (Chang, 1992; Meyers, 1992).

All three minority quasi-council representatives had extensive experience in community service. For example, Will Baca, known as an active environmentalist, protested against an incinerator and land fill construction plan in the neighboring areas of Hacienda Heights hillside in 1982. In 1990, he formed the "Dump The Dump” group that lobbied against expansion of the Puente Hills Landfill, and co-founded the California Alliance in Defense of Residential Environments, concerning related environmental protection activities in the east San Gabriel Valley (Hudson, 1990; Scauzillo, 2006). The other two Chinese candidates, Eugene Y. Chang and Cecilia L. Yu, both were active in Chinese community in the southern California. Eugene Y. Chang served as the president of the East Valley chapter of the Chinese American Association of Southern California; Cecilia L. Yu was a senior immigration attorney, and heavily involved in United Way and the Hacienda Heights Chinese Association, and provided free legal services to needy local Asian and Latino residents (Romney, 1993). The records of these three minority candidates showed the close link they had with ethnic social networks and formidable connection with community services. The implication was that Chinese and Latinos had gradually risen to political power in the local politics.

In short, although Chinese and Latino groups did not attend municipality discussions in full and few minority leaders were engaged in the process of cityhood application, their mobilization for the pseudo-city council election marked the emergence of their political power. Local Chinese, along with Latino and other Asian residents, began to exert their visible political influence upon the local community agenda, which would culminate in the next round of cityhood movement in 2003.

\subsection{Chinese in Cityhood Activity in 2003}

The third attempt to incorporate Hacienda Heights in 2003 was unique for Chinese residents, compared to the previous attempt in 1992. Chinese had become a main participation group in the incorporation process. Since the effort to incorporate the cityhood was rejected at the polls in 1992, it would take ten years for the next round to 
get off the ground.

At the end of 1990s, local activists such as Barbara Fish, Felicia Minardi and Ken Manning, sponsored by the Hacienda Heights Chinese Association members, such as Shan Lee, served as the chief petitioners and represented the newly-founded Hacienda Heights Cityhood Organization. On December 9, 1999, Hacienda Heights Cityhood Organization had submitted a petition of 8207 signatures to initiate the application, of which only 6638 signatures were found to be valid by the LAFCO, a shortage of 101 signatures to the required 6739 signatures of $25 \%$ registered voters. However, within the 15-day period provided by Code Section 56706 of the Cortese-Knox Local Government Reorganization Act of 1985, the Hacienda Heights Cityhood Organization submitted additional signatures on February 7, 2000. After LAFCO examined the Comprehensive Fiscal Analysis (CFA) and approved the incorporation application on August 22, 2002, the cityhood proposal, the Measure $\mathrm{HH}$, was scheduled to take effect on June 3, 2003, with the election of five city-council members once the incorporation occurred (Winton, 1999; Tanaka, 2002; 2003). ${ }^{15}$

With reference to the case in 1992, city council election had seventeen candidates, including six white, five Latino, one African America and five Chinese candidates, Scarlet (Liu) Treu, David S. Fong, Shan Lee, Norman Hsu, and Tom Chang. ${ }^{16}$ Compared to the 1992 election where whites accounted more than half of total candidates, the new election in 2003 mirrored the demographic makeup in the town, in which the population was nearly equally divided between Asians, Latinos, and Europeans.

Given that the cityhood proposal was overthrown with slight majority ballots in 1992, the pro-incorporation group had high expectations for the passage of Measure HH. This optimistic expectation was shored up when many ethnic minorities in local HHIA discussed and became involved in this incorporation process. This process did not happen in the previous municipality movement in 1992. Shan Lee, the local Chinese representative in HHIA, consulted with Barbara Fish and Felicia Minardi to advance the incorporation petition. Other Chinese candidates, such as Norman Hsu, David S. Fong and Tom Chang all expressed their support for the incorporation and promoted this issue in the local Chinese community. Local Latino leaders, such as Joseph A. Perez, heavily supported cityhood in the local Hispanic community as well.

Nevertheless, the turnout of Measure HH came with surprise outcome: the no-votes reached 7180, accounting for $62.67 \%$ of total ballots. Only 4276 votes favored incorporation, making up $37.33 \%$ of all ballots, less than one thousand votes that supported the election eleven years ago (Lota, 2003; Pierson, 2003). The overwhelming ballots against cityhood incorporation demonstrated an interesting phenomenon. First, Los Angeles County's indefinite attitude toward the incorporation marked an influential effect for local incorporation's development. In general, although the LA County Board of Supervisors usually publicly announced neutrality in most cases of incorporation attempts, the loss of revenues to the County often forced the Supervisors to utilize technical ways in the application process to invalidate the incorporation petitions. Therefore, in many cases the finding was that LAFCO inspected petition signatures with great care, even examining handwriting for authenticity and disqualifying the incorporation application on the grounds of fraudulent activities.

Moreover, in line with growing incorporation movements across the United States after 1980, the Californian Legislature also enacted related regulations to counteract cityhood enthusiasm, using "neutrality revenue", which went into effect in 1991. This "neutrality revenue", regulated by Cortese-Knox-85 bill, meant that all new cities had to pay a fee to counties for previous services rendered. This bill gave counties a hand to fight incorporation. What cityhood proponents nicknamed as the "alimony fee", it was difficult for the establishments of cityhoods after the Cortese-Knowx-85 bill was passed. For Hacienda Heights, the required revenue neutrality payment reached \$19 million, causing Hacienda Heights to have a projected fiscal deficit of about \$71,000 in 19 years. This revenue neutrality payment was a grave point of concern for many locals because of impending financial bankruptcy if the municipality was created. From the flyers distributed by anti-incorporation organizations, "Vote No on Cityhood for Hacienda Heights", the "revenue neutrality" was an effective weapon to persuade local swing voters that a city would increase the tax burden for them (Tanaka, 2002; 2003). As Jim Crabtree, a local leader of anti-cityhood movement, claimed: "It (incorporation) is going to be a financial disaster." (Pierson, 2003). This tax-raise rumor also was distributed extensively in local Chinese community. Hilary

\footnotetext{
${ }^{15}$ The Local Agency Formation Commission for Los Angeles County, Hacienda Heights Incorporation Proposal: Executive Officer Summary Report, December 11, 2002; The Local Agency Formation Commission for Los Angeles County, Hacienda Heights Incorporation: Comprehensive Fiscal Analysis, August 22. 2002.

${ }^{16}$ All five Chinese candidates in the election were first-generation immigrants, and aside from Norman Hsu, other four candidates were all Taiwan-born. It showed that foreign-born Chinese sustained their power to lead the ethnic political participation in this election, although some staff of their teams were joined by second-generation Chinese voluntary workers.
} 
Chang, a local Chinese resident responded that many of her relatives and friends, who once supported Measure C in 1992, casted no-vote to the Measure HH in 2003 because they worried that the neutrality revenue would ruin the town's budget, leading locals to pay more taxes. ${ }^{17}$

Besides, the motive for the overwhelming votes against cityhood was a result from the primary fear that the Chinese would control the council and that the city would be transformed into the next "Monterey Park". This anxiety was a belief held by non-Chinese residents that "Chinatownized” commercial strips and Asian shopping outlets that sprung up in the last two decades, already degraded the status of their town and deterred investors. The tension was exacerbated when five Chinese candidates launched a high-profile electoral strategy, with their slogans and banners distributed in most streets and municipal areas and their campaign vehicles frenziedly shuttling in and out of the town. Local TV channels were also broadcasting Chinese electoral advertisements and showing that the five Chinese candidates' fundraising campaigns outclassed that of their competitors.

For example, Scarlet Treu's fundraising party on April 16 attracted over 600 attendants, who donated several hundred thousand dollars to her campaign. The fundraising meetings of David Fong, Norman Hsu, Shan Lee, and Tom Chang, were also highly successful, each of them holding lush parties and collecting an abundance of donations. In addition, during the last days of the election, four male Chinese candidates even employed a joint electoral strategy and gathered hundreds of supporters to engage in street greeting meetings. These high-pitched electoral campaigns were a step to final victory for the Chinese candidates.

Furthermore, on May 9, a forum, sponsored by the Indochinese American Political Action Committee, the Chinese American Association of Southern California, Hacienda Heights Area Chinese Association and the Chinese Elected Officials of southern California, rallied local residents to become even more involved. The San Gabriel Valley Tribune, a local newspaper, published the five Chinese candidates' political statements in Mandarin but the forum was publicly criticized by Dennis Mathewson, a leader of the "No on cityhood”, blaming that local Chinese was "trying to pull 'the race card'.... five Asians are not going to control the community. We are a [community] that is divided equally and we are getting sick and tired of this race thing they keep pulling." (Rubin, 2003). These incidents strengthened the beliefs by local residents that a "Chinese voting bloc" might threaten their daily lives. Despite that, on May 17, candidate Norman Hsu issued a newsletter, published in $\mathrm{Ha}$ cienda Heights Community News, to encourage local Chinese voters to make "history by electing not more than three Chinese-American City Council members", and warned that by electing more than five Chinese to the council would create a strong backlash and possibly a recall, which would cause shame. However, the Chinese diaspora was rapidly dispersed in local, particularly white, community (Tanaka, 2003). As local Chinese elected official, Joseph Chang, concluded: "Chinese high-profile strategy in the cityhood election caused critical setback and a strong sense of crisis for locals. It prompted enthusiasm among non-Chinese voters that has never before been seen in the preceding elections of HLPUSD. They all came out to vote against a city-to-be controlled by mono-ethnic group." 18

Indeed, the incorporation movement of Hacienda Heights was a complicated agenda, causing a demographic shift, transforming the local governing system, encouraged political competition among different ethnic groups, and, most important, opened up a multitude of respective concerns of individual voters in the communities where they lived.

The overwhelming majority of residents who rejected the cityhood incorporation did not suggest a backward trend that locals lacked a sense to further engage in local politics; instead, their voting behaviors were dominated by panics over change or other non-political factors. For local Chinese voters, the increasingly active involvement in the discussion of cityhood agenda, regardless of pros and cons, as well as their perceptions for the semi-racist rhetoric during the election, all embodied objective awareness. As Cody Lin, a local Chinese resident, observed:

The cityhood activity in 2003 educated local Chinese, who were steadily familiar with American political mechanism, with the comprehension of a complicated political agenda beyond Chinese convention of equating political participation to pure ethnic representation. It made many Chinese voters to participate in civic conversations with both Chinese and non-Chinese residents, and increase their identity to the local community, no matter they voted yes or no to the Measure $\mathrm{HH}^{19}$

However, putting aside splitting votes on the incorporation issue, the election of pseudo-council members

\footnotetext{
${ }^{17}$ Interview with Hilary Chang, Date: October 5, 2011.

${ }^{18}$ Interview with Joseph Chang, Date: April 29, 2012.

${ }^{19}$ Interview with Cody Lin, Date: August 10, 2011.
} 
genuinely illustrated Chinese growing interests and impact in local politics: two Chinese candidates, Scarlet Treu, 2882 (7.59\%) and David Fong, 2756 (7.26\%), along with two European candidates, Kenneth R. Manning, 3775 (9.94\%); Charles M. House, 3569 (9.40\%), and Latino candidate, Felicia F. Minardi, 2813 (7.41\%), were among the top five vote-getters in the election. Another three Chinese candidates also listed from sixth to eighth, with simply a hundred-votes gap between each of the candidates (see Table 1). This result showed stronger power in the Chinese voting base.

In fact, the five Chinese candidates had formidable service history in the local Chinese community. David Fong worked as campaign manager for Eugene Chang in 1992. From 1997 to 1999, he served as the president of Hacienda Heights Chinese Association and chaired the Taiwan University Alumni Association and JCUAA in the 1997 and 1999, respectively. Afterwards, he also created Hacienda Heights Royal Lions Club and California Business Foundation in 2005 and 2008, respectively. As a noted immigration attorney, he founded the Chinese Attorney Association of North America, and served as the law counselor for many local Chinese organizations, including the Sino-American Certified Public Accountants Association, Hacienda Heights Chinese Association, as well as local Chinese newspapers such as Chinese Daily News, Sino News and Shin Taso News. Tom Chang was a professional engineer and worked for a longtime in the Hacienda Heights Chinese PTA. Shan Lee was the vice executive president of Daum Commercial Real Estate Services, and was involved in Hacienda Heights Chinese Association and Chiao Tung University Alumni Association. Scarlett Treu was a business manager, and was engaged in regional and local Chinese organizations, such as JCUAA and Hacienda Heights Chinese PTA. ${ }^{20}$ From the backgrounds of these five Chinese candidates, it is evidenced that close connections and wide social networks is an important characteristic in local Chinese communities.

In addition, these five Chinese candidates were also connected differently with the non-Chinese community. For instance, Norman Hsu created a social network beyond the Chinese community when he served as a board

\begin{tabular}{|c|c|c|}
\hline & Votes & Vote Percentage (\%) \\
\hline Kenneth R. Manning & 3775 & 9.9 \\
\hline Charles M. House & 3569 & 9.4 \\
\hline Scarlet Treu & 2882 & 7.6 \\
\hline Felicia F. Minardi & 2813 & 7.4 \\
\hline David Fong & 2756 & 7.3 \\
\hline Norman Hsu & 2622 & 6.8 \\
\hline Tom Chang & 2608 & 6.8 \\
\hline Shan Lee & 2572 & 6.7 \\
\hline Barbara L. Fish & 2344 & 6.1 \\
\hline Henry B. Pedregon & 2113 & 5.5 \\
\hline Fred Chyr & 1942 & 5.0 \\
\hline Jefferey K. Yann & 1874 & 4.9 \\
\hline Henry E. Gonzales & 1838 & 4.8 \\
\hline Joseph A. Perez & 1556 & 4.0 \\
\hline Sidney W. Street & 1213 & 3.2 \\
\hline Rudy Almeida & 922 & 2.4 \\
\hline Carmelita Louise Trujillo & 901 & 2.3 \\
\hline
\end{tabular}

Source: Los Angeles County Registrar-Recorder.

\footnotetext{
${ }^{20}$ Staff writer, “Council Choices for Hacienda Heights,” San Gabriel Valley Tribune, May 21, 2003.; Chinese Daily News, February 4, 2003; Chinese Daily News, May 28, 2003; Interview with David Fong, Date: June 17, 2012; Interview with Norman Hsu, Date: June 21, 2012.
} 
member of HLPUSD, and had close contact with Kenneth R. Manning, who served as member of Upper San Gabriel Valley Municipal Water District and HLPUSD. Because of this good relationship, Hsu and Manning decided to jointly campaign in this election (Woo, 1987; Walker, 1995). David Fong also had plenty of connections involving non-Chinese matters. He served as the law consultant for Los Angeles Chief Sheriff Lee Baca and Federal Representative Gary Miller. In the election campaign of 2003, he also cooperated with the local Latino candidate, Joseph A. Perez; Shan Lee worked as the board representative of HHIA, and served as the co-sponsor for the incorporation application in 2003. He also frequently consulted with the Los Angeles County's Regional Planning Committee regarding zoning and land use issues because of his background in the real estate business. Tom Chang was also a member of HHIA, maintaining a close relationship with faculties and other Hacienda Heights PTA when he headed the local Chinese PTA in early 2000s.

The only female Chinese candidate, Scarlett Treu, was also favorably perceived by the non-Chinese community. Scarlett Treu was in a better position to interact with mainstream organizations because of her marriage to a German American judge, Rolf Treu. She worked as a consultant for Federal Representative Gary Miller, and was involved in the passage of Measure R, Mt. SAC's Bond Measure, in 2001, as well as serving as the vice president of Mt. SAC Foundation. She joined the local Women's Club and participated in HHIA in 2000. Experiences with the non-Chinese community due to her prolific track-record helped her to gain significant endorsements from leaders of the mainstream society, including Los Angeles County Sherriff Lee Baca, Los Angeles County Supervisor Michael Antonivch, Congress Representative Gary Miller, California assemblyman Bob Pachec, Los Angeles County district attorney Steve Cooley and former president of Mt. San Antonio College, Bill Feddersen. ${ }^{21}$ She and Shan Lee's well-connectedness with mainstream organizations and popularity resulted in their selection on the list of five recommendation candidates of San Gabriel Valley Tribune for the election in 2003. ${ }^{22}$

Due to her close relationship with the mainstream community, Scarlet Treu employed different tactics from the other four Chinese candidates in the election, for example, stressing closer cooperation with non-Chinese voters, and trying to soften her image as a mono-ethnic representative. Therefore, Scarlet was the only Chinese candidate attending the June first meeting, held in the local Saint Marks Lutheran Church, targeting senior white citizens. $^{23}$ The strategy to appeal to non-Chinese ballots worked in her favor when she appeared in the May ninth Chinese-exclusive forum held by the San Gabriel Valley Tribune and was welcomely received. ${ }^{23}$

Many white residents felt that Scarlet carried their interests at heart and voted against incorporation. This meant that she had to change her electoral strategy and attitude toward the municipality agenda in the last days of the election providing for anti-incorporation ballots. This tactic caused criticism from some Chinese candidates and local Chinese inhabitants who blamed her for inconsistency and moving ground (Tanaka, 2003$){ }^{23}$ However, Scarlett Treu's electoral tactic, as a two-tiered candidate who focused first on the mainstream community and then on the Chinese/Asian American community, was effective, particularly for the local non-Chinese community, leading her to become the Chinese candidate with the most ballots in the election.

\section{Conclusions}

From the events described in the aforementioned analysis, it is evident that Chinese involvement in the cityhood movement of Hacienda Heights contributed to transformation; from outsiders in 1980s, marginal participants in 1992, to significant players in 2003. Participation in the incorporation agenda, whatever the benefits and disadvantages, gradually developed further.

While exerting political power in ethnic representation, local Chinese also were increasingly aware of the significance of cooperation with other local ethnic groups for different types of political reasons. Local Chinese were given opportunities to engage in political activities, while also recognizing and cultivating external problems in their path to exercise political power.

In addition, reflecting on the events of Hsi Lai Temple dispute in 1980s to cityhood movement in 2003, it is difficult to classify how local communities, especially longtime-residential whites, responded to transformation in their multi-ethnic neighborhood. Anxiety over growing power of minority groups, such as Chinese (Asian) immigrants, can create a reversal of incorporation issues. This is because minority groups are playing a stronger

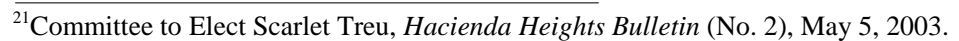

${ }^{22}$ Staff writer, “Council Choices for Hacienda Heights,” San Gabriel Valley Tribune, May 21, 2003.

${ }^{23}$ Interview with Scarlett Treu, Date: June 11, 2012.
} 
role in deciding the outcomes of cityhood movements and is their involvement not taken lightly anymore. Investigating the value of multi-ethnic communities in American suburbs can surely make a contribution to the literature.

\section{References}

Arax, M. (1987). Nation’s 1st Suburban Chinatown. Los Angeles Times, April 6, 1987.

Arax, M. (1987). Taiwan Native Pursues American Ways A Woman of Independent Mind Series: Asian Impact. Los Angeles Times, April 16, 1987.

Avery, S. (1981). Cityhood Foes Dispute Claims About Funds. Los Angeles Times, November 8, 1981.

Barker, M. (1974). Hacienda Heights Unit Will Try for Cityhood. Los Angeles Times, April 25, 1974.

Barker, M. (1981). Hacienda Heights Cityhood Petition Campaign Ready to Begin. Los Angeles Times, March 12, 1981.

Birkinshaw, J. (1982). Board Bows to Hacienda Heights Plea. Los Angeles Times, December 12, 1982.

Birkinshaw, J. (1982). Forgery Asserted in Bid for Hacienda Heights Cityhood. Los Angeles Times, August 12, 1982.

Birkinshaw, J. (1982). Hacienda Heights City a Step Closer. Los Angeles Times, April 29, 1982.

Birkinshaw, J. (1982). Hacienda Heights Cityhood Backers Win New Time Extension. Los Angeles Times, November 25, 1982.

Birkinshaw, J. (1982). Hacienda Heights Clears First Step. Los Angeles Times, May 6, 1982.

Birkinshaw, J. (1982). Hacienda Heights Election Clouded. Los Angeles Times, August 12, 1982.

Bollans, J. C., \& Scoot, S. (1951). Local Government in California. University of California Press, Berkeley.

Bond, M. (1990). Houses Stand Where Orchards Grew: Hacienda Heights. Los Angeles Times, October 14, 1990.

Bond, M. (1996). Rowland Heights: In an Area Where a Ranch and Wheat Farms Once Stood, a Community Flourishes with a Burgeoning Asian Influence. Los Angeles Times, April 21, 1996.

Chang, I. (1990). Temple Archives Measure of Peace in Hacienda Heights. Los Angeles Times, July 7, 1990.

Chang, I. (1991). County Panel Approves Cityhood Election: Commission Finds Proposed City Financially Feasible, Election Possible in Spring. Los Angeles Times, December 12, 1991.

Chang, I. (1991). Now Comes Hard Part: After Deciding That Cityhood Would Be Viable Economically, County Officials Prepare to Draw the City Limits. Los Angeles Times, October 27, 1991.

Chang, I. (1991). They Hope 3rd Time IS Charm for Cityhood: Hacienda Heights: After Two Failed Attempts, Supporters Are Resurrecting the Bid to Turn This Diverse Community into the County’s Newest City. Los Angeles Times, March 7, 1991.

Chang, I. (1992). Elections: Attempt to Incorporate Lacks Single Rallying Cry. Los Angeles Times, May 24, 1992.

Chang, I. (1992). Elections: Attempt to Incorporate Lacks Single Rallying Cry. Los Angeles Times, May 24, 1992.

Chee, M. W. L. (2005). Taiwanese American Transnational Families: Women and Kin Work. Routledge \& Francis Group, New York.

Dai, I. (2005). Trash Turns Treasure for Two Communities. San Gabriel Valley Tribune, February 3, 2005.

Diaz, E. (2005). The San Gabriel Valley: A 21st Century Portrait. El Monte/South El Monte Chamber of Commerce, El Monte.

Dyer, R. L. (1961). The Growth and Development of Monterey Park, California between 1906 and 1930. Los Angeles State College, Los Angeles.

Fong, T. P. (1994). The First Suburban Chinatown: The Remaking of Monterey Park, California. Temple University Press, Philadelphia.

Frank, A. (1971). Cityhood Considered by Hacienda Heights: Feasibility Committee to Study Facts of Incorporation; Taxes Determining Factor. Los Angeles Times, April 21, 1971.

Goldbach, J. (1965). Local Formation Commissions: California’s Struggle over Municipal Incorporations. Public Administration Review, 25, 213-220. http://dx.doi.org/10.2307/973745

Hamilton, D. (1995). Developers Trying to Make Asians Buyers Feel at Home in Southland. Los Angeles Times, June 17, 1995.

Horton, J. (1995). The Politics of the Diversity: Immigration, Resistance, and Change in Monterey Park, California. Temple University Press, Philadelphia.

Hsu, S. (2005). It Isn’t a City Council. Whittier Daily News, November 5, 2005. 
Hudson, B. (1990). Dump: Activists Maintain Southland Is Trashing Them. Los Angeles Times, October 11, 1990.

Hudson, B. (1990). Neighbors Fight Dump Expansion: The Puente Hills Landfill Is One of Seven Listed for Possible Expansion, but Residents of Hacienda Heights Object. Los Angeles Times, October 4, 1990.

Hudson, B. (1990). Neighbors Fight Dump Expansion: The Puente Hills Landfill Is One of Seven Listed for Possible Expansion, but Residents of Hacienda Heights Object. Los Angeles Times, October 4, 1990.

Hudson, B. (1990). Residents of Hacienda Heights Rally against Dump’s Growth. Los Angeles Times, October 4, 1990.

Jimenez, F., Garcia, A. M., \& Garcia, R. A. (2007). Ethnic Community Builders: Mexican Americans in Search of Justice and Power-The Struggle for Citizenship Rights in San Jose. Alta Mira, Lanham, California.

Klein, K. (1997). Learning Art of Selling to Asian Buyers. Los Angeles Times, April 20, 1997.

Krikorian, G. (1994). Caught in the Middle: Service-Poor Unincorporated Areas Can Seem Worlds Apart from Neighboring Cities. Los Angeles Times, September 15, 1994.

Lepage, A. (1994). Landfill Permit Ruled Invalid. Los Angeles Times, February 17, 1994.

Levitt, P., De Wind, J., \& Vertovec, S. (2003). International Perspectives on Transnational Migration: An Introduction. International Migration Review, 37, 565-575. http://dx.doi.org/10.1111/j.1747-7379.2003.tb00150.x

Lewis, P. G. (2000). The Durability of Local Government Structure: Evidence from California. State \& Local Government Review, 32, 36-37. http://dx.doi.org/10.1177/0160323x0003200103

Li Wei (1998). Building Ethnoburbia: The Emergence and Manifestation of the Chinese Ethnoburb in Los Angeles’ San Gabriel Valley. Journal of Asian American Studies, 2, 1-28. http://dx.doi.org/10.1353/jaas.1999.0009

Lota, L. (2003). Hacienda Heights Votes No on Cityhood. Associated Press, June 4, 2003.

Markus, B. P. (2008). Beautification Project in Hacienda Heights Reaches its Final Stages. Whittier Daily News, December 5 , 2008.

Meyers, M. (1992). Final Election Returns. Los Angeles Times, June 4, 1992.

Monterey Park 75th Anniversary Committee and Historical Society of Monterey Park (1991). Reflections, from 1916: Monterey Park's Past, Present and Future. Monterey Park 75th Anniversary Committee, Monterey Park.

Newton, E. (1988). Blessings of Buddha 5,000 Participate in Consecration of New Temple. Los Angeles Times, December 1, 1988.

Pierson, D. (2003). Cityhood Vote Divides Hacienda Heights. Los Angeles Times, June 1, 2003.

Pierson, D. (2003). Hacienda Heights Wonders: Now What? Los Angeles Times, June 5, 2003.

Romney, L. (1993). Chinese Americans Make Political Strides Community: Stereotypes: Stereotypes and Cultural Misunderstandings Persist, but Leaders Have Begun to Lay the Foundation for Future Success. Los Angeles Times, November 28, 1993.

Rubin, K. (2003). Race Issue Raised over Cityhood Discussion: Asian-Only, Mandarin Format Called Divisive. San Gabriel Valley Tribune, May 9, 2003.

Saito, L. T. (1998). Race and Politics: Asian Americans, Latinos, and Whites in a Los and Angeles Suburb. University of Illinois Press, Urbana.

Scauzillo, S. (2006). Environmentalist Wilfred Baca Dies. Whittier Daily News, April 5, 2006.

Schiesl, M. J. (1982). The Politics of Contracting: Los Angeles County and the Lakewood Plan, 1954-1962. Huntington Library Quarterly, 45, 227-243. http://dx.doi.org/10.2307/3817297

Schoner, C. A. (2006). Suburban Samurai: The Asian Invasion of Southern California's San Gabriel Valley. CAS Associates, Diamond Bar.

Smith, C. (2011). Guide to Cortes-Knox-Hertzberg Local Government Reorganization Act of 2000. Los Angeles, CA: Assembly Committee on Local Government.

Staff Writer (1982). Agency Gets Incorporation for Hacienda Heights. Los Angeles Times, January 14, 1982.

Staff Writer (1991). Hacienda Heights: Cityhood Effort Advances. San Gabriel Valley Digest, July 28, 1991.

Staff Writer (1991). Hacienda Heights: Cityhood Papers Submitted. San Gabriel Valley Digest, June 27, 1991.

Staff Writer (1993). Hacienda Heights: Landfill Expansion Rejected. San Gabriel Valley Digest, October 14, 1993.

Staff Writer (1993). Hacienda Heights: Landfill Permit Renewed. San Gabriel Valley Digest, May 6, 1993.

Staff Writer (1995). Koll/Akins form New Strategic Business Entity to Pursue Residential Opportunities. Business Wire, April 25, 1995.

Staff Writer (1998). Getting Ready for Primary Fight: APA Candidates Concentrated in Southern California. Asian Week, June 3, 1998. 
Staff Writer (2002). Let Community Ponder Self-Rule. San Gabriel Valley Tribune, November 28, 2002.

Staff Writer (2003). Council Choices for Hacienda Heights. San Gabriel Valley Tribune, May 21, 2003.

Staff Writer (2003). Council Choices for Hacienda Heights. San Gabriel Valley Tribune, May 21, 2003.

Staff Writer (2003). Declining Cityhood. Pasadena Star News, May 20, 2003.

Staff Writer (2003). Hacienda Heights Cityhood Fails. San Gabriel Valley Tribune, June 5, 2003.

Tanaka, R. (2002). Cityhood or Status Quo Hacienda Heights: Cityhood for Hacienda Heights Will Go to the Voters. San Gabriel Valley Tribune, December 11, 2002.

Tanaka, R. (2002). County to Study Cityhood “Alimony”. San Gabriel Valley Tribune, November 24, 2002.

Tanaka, R. (2003). Candidate’s Letter Draws Opponents: Ethnicity at Issue in Election. San Gabriel Valley Tribune, May 17, 2003.

Tanaka, R. (2003). Cityhood Showdown Looms: Battle Lines Drawn in Hacienda Heights. San Gabriel Valley Tribune, February 8, 2003.

Tanaka, R. (2003). Hacienda Heights Cityhood Backed: Members Protest Board Resolution. San Gabriel Valley Tribune, March 18, 2003.

Tanaka, R. (2003). Hacienda Heights Council Candidates Describe Goals. San Gabriel Valley Tribune, April 19, 2003.

Tanaka, R. (2003). HHIA Votes to Support Cityhood, Members Protest Board Resolution. San Gabriel Valley Tribune, March 20, 2003.

Tanaka, R. (2003). Opposing Sides Debate Cityhood for Heights. San Gabriel Valley Tribune, April 29, 2003.

Torres, L. (1988). Largest North American Buddhist near Completion in LA Suburb. San Gabriel Valley Tribune, July 10.

Trounson, R. (1980). Hacienda Heights in 80s: Growing Pains Prompt Push for Incorporation. Los Angeles Times, October 19, 1980.

Wagner, J. (2010). Longtime Hacienda Heights Leader Fish Dies. Whittier Daily News, February 5, 2010.

Walker, C. (1995). Recall Drive Targets Entire Hacienda La Puente School Board: Fund Mismanagement and Nepotism Are among the Charges. Members Deny Any Wrongdoing. Los Angeles Times, March 2, 1995.

Wen Ming, Lauderdale, D. S., \& Kandula, N. R. (2009). Ethnic Neighborhoods in Multi-Ethnic America, 1990-2000: Resurgent Ethnicity in the Ethnoburbs? Social Forces, 88, 425-460. http://dx.doi.org/10.1353/sof.0.0244

Winton, R. (1993). Landfill Fights Curbs on Expansion. Los Angeles Times, September 2, 1993.

Winton, R. (1994). County Supervisors Clear Way for Landfill Expansion. Los Angeles Times, August 11, 1994.

Winton, R. (1999). Hacienda Heights Cityhood Issue arises again. Los Angeles Times, August 18, 1999.

Woo, E. (1987). Ethnic Diversity Puts School Districts to Test Series: Asian Impact. Los Angeles Times, April 9, 1987.

Wysocki Jr., \& Moving, B. (1996). Influx of Immigrants Adds New Vitality to Housing Market. The Wall Street Journal, October 10, 1996. 